\title{
Regulatory B Cell
}

National Cancer Institute

\section{Source}

National Cancer Institute. Regulatory B Cell. NCI Thesaurus. Code C113502.

A subset of B-cells that can negatively regulate immune responses mediated by $T$-cells.

These B-lymphocytes produce interleukin-10. 